\title{
An overview on Hypericum species of Turkey
}

\author{
Esra Eroğlu Özkan* and Afife Mat \\ Department of Pharmacognosy, Faculty of Pharmacy, Istanbul University, 34116, Istanbul, Turkey.
}

Accepted 28 January, 2013

\begin{abstract}
The genus Hypericum (Hypericaceae) is represented by nearly 100 taxa grouped under 19 sections in Turkey. Among them, 45 species are endemic. All members of the genus may be referred to as St. John's wort in the world. The genus is known as "sari kantaron, kantaron, binbirdelik otu, mayasil otu" and most of them, especially $H$. perforatum, have been used for the treatment of burns, wounds, haemorroids, diarrhorea and ulcers in Turkish traditional medicine. The pharmacological studies showed that this species has several activities: anti-depressant, anti-inflammatory, anti-microbial, antiviral, anti-nociceptive and wound healing. The chemical composition of the Hypericum species is composed of naphthodianthrones (especially hypericin and pseudohypericin), acylphloroglucinol derivatives (especially hyperforin and adhyperforin), flavonoids (especially quercetin, quercitrin, hyperoside and biapigenin), tannins and volatile oils. Investigations on the chemical composition and biological activities, as well as hypericin content of Turkish Hypericum species, have been carried out for about 25 years. The aim of this study was to review and summarise important studies about Turkish Hypericum species. Endemic species are indicated with (e) in the text.
\end{abstract}

Key words: Hypericum species, Turkey, endemic, chemical composition, biological activity, agricultural study, traditional use.

\section{INTRODUCTION}

\section{Traditional uses of Hypericum species in Turkey}

Hypericum species have been used in traditional medicine in Anatolia for centuries. The existence of four species including; H.crispum, $H$. perforatum, $H$. perfoliatum and $H$. coris as medicinal plants was reported in Dioscorides' Materia Medica. Various traditional uses have been reported for $H$. atomarium, $H$. aviculariifolium, $H$. cerastoides, $H$. calycinum, $H$. confertum subsp. confertum, $H$. confertum var. stenobotrys, $H$. heterophyllum, $H$. hyssopifolium, $H$. hyssopifolium subsp. elongatum var. elongatum, $H$. lydium, $H$. montbretii, $H$. olympicum, $H$. orientale, $H$. scabrum, $H$. ternatum, $H$. thymifolium, $H$. triquetrifolium and mainly $H$. perforatum (Yesilada et al., 1993; Yesilada et al., 1995; Honda et al., 1996; Tuzlaci and Tolon, 2000; Tuzlaci and Aymaz, 2001; Keskin and Alpinar, 2002; Ezer and Avci, 2004; Bulut, 2006; Buyukgebiz, 2006; Ecevit and Ozhatay, 2006; Ezer and Mumcu, 2006; Mart, 2006; Cimen, 2007; Akgul, 2008;

\footnotetext{
${ }^{*}$ Corresponding author. E-mail: esraeroglu@gmail.com
}

Demirci, 2010; Aktan, 2011; Kizilarslan, 2008) in the form of infusion, decoction, ointment and oleat (dried herbs with flowers are kept in olive oil for 1 month and filtered through muslin) in Turkey. Table 1 shows species having traditional uses.

\section{AGRICULTURAL STUDIES}

A study was undertaken to enhance the germination rate of $H$. aviculariifolium subsp. depilatum var. depilatum (e) seeds. Results revealed that the seeds have exogenous dormancy and light is required for germination (Cirak et al., 2007a). The ontogenetic and morphogenetic variation of hypericin, chlorogenic acid and flavonoids was determined in $\mathrm{H}$. origanifolium. Hypericin, quercetin and quercitrin content in whole plant increased during the course of ontogenesis, and the highest level was reached in blooming stage whereas, hyperoside content of whole plant decreased linearly with advancing of development stages, and the highest level was observed at vegetative stage. Among different tissues, reproductive parts accumulated the highest level of hypericin, quercetin and 
Table 1. The traditional uses of Hypericum species in Turkey.

\begin{tabular}{|c|c|c|c|}
\hline Hypericum species & Traditional uses & Administration & References \\
\hline H. atomarium & Stomach diseases, enteritis, sedative & Inf. (int) & Vural (2008) \\
\hline H. aviculariifolium & Urethra diseases & Inf. (int) & Keskin and Alpınar (2002) \\
\hline H. cerastoides & To against diarrhea & Inf. (int) & Kızılarslan (2008) \\
\hline H. calycinum & To abolish spasm, anti-asthmatic & Dec. (int) & Aktan (2011) \\
\hline H. confertum subsp confertum & Anti-asthmatic, wound healing & $\begin{array}{l}\text { Inf. (int), Oleat } \\
\text { (ext) }\end{array}$ & Buyukgebiz (2006) \\
\hline H. confertum var. stenobotrys & To abolish spasm, stomach diseases & Inf. (int) & Buyukgebiz (2006), Bulut (2006) and Mart (2006) \\
\hline H. heterophyllum & Anti-inflammatory & Oleat (ext) & Unal et al. (2008) \\
\hline $\begin{array}{l}H \text {. hyssopifolium and } H \text {. } \\
\text { hyssopifolium subsp. elongatum } \\
\text { var. elongatum }\end{array}$ & $\begin{array}{l}\text { To abolish spasm, against diarrhea, hemorrhoid, } \\
\text { and as a sedative, anti-helmintic, antiseptic against } \\
\text { eczema and as an anti-fungal for various fungal } \\
\text { disorders, psoriasis }\end{array}$ & $\begin{array}{l}\text { Inf. (int), Oleat } \\
\text { (ext) }\end{array}$ & Unal et al. (2008) \\
\hline H. Iydium & $\begin{array}{l}\text { To treat indigestions and stomach diseases, } \\
\text { hemorrhoid }\end{array}$ & Inf. (int) & $\begin{array}{l}\text { Yesilada et al. (1995), Sezik et al. (2001) and Yesil } \\
\text { (2007) }\end{array}$ \\
\hline H. montbretii & Eczema & Dec. (int) & Keskin and Alpınar (2002) \\
\hline H. olympicum & For stomach ache, inflamed wounds, cuts. & $\begin{array}{l}\text { Dec., int. } \\
\text { Dec., ext. }\end{array}$ & Tuzlacı et al. (2001) \\
\hline H. orientale & Stomach diseases, sedative & Inf. (int) & Ezer (2006) and Tatlı et al. (2009) \\
\hline \multirow{6}{*}{ H. perforatum } & $\begin{array}{l}\text { Kidney stones, urinary diseases, diabetes, } \\
\text { antihypertensive, cold, stomachache, enteritis, } \\
\text { eczema, antifungal, cardiac diseases, } \\
\text { arteriosclerosis, antihemorrhagic }\end{array}$ & Dec. (int) & \multirow{6}{*}{$\begin{array}{l}\text { Yesilada et al. (1993), Yesilada et al. (1995), Tuzlacı } \\
\text { et al. (2000), Sezik et al. (2001), Tuzlacı et al. } \\
\text { (2001), Ezer (2004), Ecevit and Ozhatay (2006), } \\
\text { Kultur (2007), Cimen Oral (2007) and Demirci (2010) }\end{array}$} \\
\hline & $\begin{array}{l}\text { Asthma, insomnia, uroclepsia(forbabies), gall } \\
\text { bladder ailments, facial paralysis, gastritis, } \\
\text { chestdiseases, internal hemorrhage, bronchitis, anti- } \\
\text { inflammatory, tuberculosis, pharyngitis }\end{array}$ & Inf. (int) & \\
\hline & Wounds & Ointment (ext) & \\
\hline & Wounds, burns, cuts, herpes labialis, lip chap & Ointment (ext) & \\
\hline & Stomach diseases, diabetes, enteritis, ulcers & Ointment (ext) & \\
\hline & Stomach disease & Dec. (int) & \\
\hline H. scabrum & Hemmorroid, constipation, peptic ulcer & $\begin{array}{l}\text { Inf. (int), Oleat } \\
\text { (int) }\end{array}$ & $\begin{array}{l}\text { Yesilada et al. (1996), Ezer and Mumcu-Arısan } \\
\text { (2006) and Unal et al. (2008) }\end{array}$ \\
\hline H. ternatum & Antiasthmatic, wound healing & $\begin{array}{l}\text { Inf. (int), Oleat } \\
\text { (ext) }\end{array}$ & Bulut (2006) and Mart (2006) \\
\hline H. thymifolium & Stomach diseases & Inf. (int) & Mart (2006) \\
\hline H. triquetrifolium & Cardiac diseases, diabetes & Inf. (int) & Akgul (2008) \\
\hline
\end{tabular}

Dec. = decoction, Inf. = infusion, int. = internal, ext. = external. 
quercitrin, however, leaves produced substantially higher amount of chlorogenic acid and hyperoside. Rutin and apigenin-7-O-glucoside were detectable in all tissues only during fruit maturation (Cirak, 2007b).

Chemical and morphological variability was studied in $H$. perforatum samples collected from different locations of Northern Turkey. Hypericin content was found to be correlated positively with leaf dark gland density, however, negatively with leaf area and no correlation was detected between the other morphological traits and bioactive substances examined (Cirak et al., 2007c).

Ontogenetic, morphogenetic and diurnal variation of the total hypericins content was determined in $H$. aviculariifolium subsp. depilatum var. depilatum (e), $H$. perforatum and $H$. pruinatum. The hypericin content of leaves and whole plant was higher in $H$. aviculariifolium subsp. depilatum var. depilatum (e) whose leaves had more numerous dark glands than those of the two other species (Cirak et al., 2006a). Ontogenetic, morphogenetic and diurnal variations in total phenolic contents was investigated in $H$. aviculariifolium subsp. depilatum var. depilatum (e), $H$. perforatum and $H$. pruinatum. Phenolic contents of $H$. perforatum and $H$. pruinatum were the highest during flowering stage, although no diurnal fluctuations were observed in those species (Ayan et al., 2006).

The ability to predict the number of days for seeds of four Hypericum species $(H$. perforatum, $H$. bupleuroides, $H$. nummularioides and $H$. pruinatum) to germinate was investigated by using mathematical models based on temperature. Optimum seed germination temperature in the tested species was determined and germination time was calculated using coefficients obtained from regression models (Cirak et al., 2006b). The possibilities of domesticating $H$. crenulatum (e) collected from the Nigde-Demirkazik (Camardi) mountains were investigated. It was observed that the $H$. crenulatum (e) seeds did not germinate, thus did not adapt to the region (Inan and Kirici, 2003).

\section{CHEMICAL COMPOSITION}

The chemical composition of the Hypericum species is composed of naphthodianthrones (especially hypericin and pseudohypericin), acylphloroglucinol derivatives (especially hyperforin and adhyperforin), flavonoids (especially quercetin, quercitrin, hyperoside and biapigenin), tannins, n-alkanes, xanthones and essential oils (Bombardelli and Morazzoni, 1995; Bruneton, 1995).

\section{Naphthodianthrones and acylphloroglucinol derivatives}

Table 2 shows quantitative determination of hypericin, pseudohypericin and hyperforin in Turkish Hypericum species.

\section{Volatile compounds}

The volatile compounds of ten taxa have been investigated by using Gas chromatography (GC) and Gas chromatography/Mass spectrometry (GC/MS). Caryophyllene oxide was found as a major component in $H$. hyssopifolium var. microcalycinum and $H$. lysimachioides var. lysimachioides (Toker et al., 2006). Thirty components representing $92 \%$ of the total volatiles were characterized in $H$. Bupleuroides, and sesquiterpenes such as $\beta$-sesquiphellandrene (33.2\%) and $\beta$-caryophyllene $(20.2 \%)$ were assigned as major compounds (Demirci and Baser, 2006).

The essential oil of $H$. linarioides was found to contain 74 compounds, mainly $\delta$-cadinene $(6.9 \%)$, (Z)- $\beta$ farnesene $(5.2 \%)$, $Y$-muurolene $(5.5 \%)$, spathulenol $(4.8 \%)$, hexahydrofarnesyl acetone $(4.5 \%)$ and selinene $(4.0 \%)$. The oil was also characterized by high content of sesquiterpenes (64.2\% of total oil) (Cakir et al., 2005). $H$. adenotrichum (e), $H$. calycinum, $H$. cerastoides, $H$. montbretii, and $H$. perforatum have been investigated and their major volatile compounds were determined as follows:

Germacrene D (38\%) in $H$. adenotrichum; a-pinene $(24 \%)$ and $\beta$-pinene $(14 \%)$ in $H$. calycinum; $\alpha$-pinene $(58 \%)$, undecane $(5 \%)$ and $\beta$-pinene $(3 \%)$ in $H$. cerastoides; $\alpha$-pinene (26\%), $\beta$-pinene $(19 \%)$ and undecane $(5 \%)$ in $H$. montbretii; $\alpha$-pinene $(50 \%)$ and carvacrol $(22 \%)$ in H. perforatum (Erken et al., 2001). The volatile oil of $H$. hircinum was obtained with an efficiency of $0.73 \%$. The main components of the oil were determined as follows, $\alpha$-pinene $(88.3 \%)$, mircene $(3 \%)$, $\beta$-pinene (2.8\%), $\beta$-caryophyllene (1.5\%) and (E)- $\beta$ ocimene (1.4\%) (Demirci et al., 2008).

\section{Phenolic compounds}

$H$. hyssopifolium, $H$. pamphylicum (e), $H$. calycinum and $H$. perforatum have been investigated for their phenolic compounds. Five flavonoids (I3, II8-biapigenin, quercetin, quercetin-3-O- $\alpha$-arabinofuranoside, quercetin-3-O- $\beta$-Dgalactopyranoside, quercetin-3-O- $\beta$-D-galactopyranoside7-O- $\beta$-D-glucopyranoside) and a napthodianthrone (hypericin) were isolated, and their structures were determined by Ultar violet (UV), Infra red (IR), Nuclear magnetic resonance (NMR) and Mass spectrometry (MS) spectroscopic methods in $H$. hyssopifolium (Cakir et al., 2003).

Quercetin, quercetin 3-glucoside, and quercetin 3galactoside were isolated from $H$. pamphylicum (e) (Eroglu, 2007). A capillary zone electrophoretic (CZE) method for the determination of rutin in an ethanolic extract of the aerial parts of $H$. perforatum is described and the amount of rutin in the total plant material was found to be $0.21 \%$ (Dogrukol-Ak et al., 2001).

Two caffeoylquinic acid derivatives (chlorogenic acid 
Table 2. Quantitative determination of hypericin, pseudohypericin and hyperforin.

\begin{tabular}{|c|c|c|c|c|c|}
\hline Species & Method & $\begin{array}{c}\text { Hypericin } \\
(\mathrm{mg} / \mathrm{g})\end{array}$ & $\begin{array}{c}\text { Pseudohypericin } \\
(\mathrm{mg} / \mathrm{g})\end{array}$ & $\begin{array}{l}\text { Hyperforin } \\
(\mathrm{mg} / \mathrm{g})\end{array}$ & Reference \\
\hline H. androsaemum & LC/MS & $<0.01$ & $<0.01$ & 0.09 & \multirow{6}{*}{ Smelcerovic et al. (2008) } \\
\hline H. aviculariifolium & LC/MS & 0.66 & 0.58 & 0.02 & \\
\hline H. bithynicum & LC/MS & 1.05 & 2.03 & 0.15 & \\
\hline H. heterophyllum & LC/MS & 0.51 & 0.32 & 0.08 & \\
\hline H. hirsitum & LC/MS & 0.54 & 0.38 & 0.20 & \\
\hline \multirow{2}{*}{ H. hyssopifolium } & LC/MS & 0.52 & 0.46 & 0.04 & \\
\hline & HPLC & 0.03 & 0.051 & - & Ayan et al. (2004) \\
\hline H. linarioides & LC/MS & 0.34 & 0.56 & $<0.01$ & Smelcerovic et al. (2008) \\
\hline H. Iydium & UV & 1.21 & - & - & Cirak (2006) \\
\hline H. montanum & LC/MS & 1.13 & 1.56 & $<0.01$ & \multirow{2}{*}{ Smelcerovic et al. (2008) } \\
\hline \multirow{2}{*}{ H. montbretii } & LC/MS & 0.74 & 2.10 & 3.45 & \\
\hline & HPLC & 2.52 & 3.58 & - & Ayan et al. (2008) \\
\hline H. nummularioides & LC/MS & 0.20 & 0.18 & 0.25 & \multirow{3}{*}{ Smelcerovic et al. (2008) } \\
\hline H. orientale & LC/MS & 0.02 & 0.04 & 0.03 & \\
\hline \multirow{2}{*}{ H. origanifolium } & LC/MS & $<0.01$ & 0.01 & $<0.01$ & \\
\hline & HPLC & - & 0.93 & 1.63 & Cirak et al. (2008) \\
\hline H. pamphylicum (e) & HPLC & 0.00016 & - & trace & Eroglu (2007) \\
\hline \multirow{2}{*}{ H. perfoliatum } & LC/MS & 0.29 & 0.23 & 0.14 & Smelcerovic et al. (2008) \\
\hline & HPLC & - & 2.62 & 1.84 & Ayan et al. (2008) \\
\hline \multirow{3}{*}{ H. perforatum } & LC/MS & 3.47 & 3.54 & 5.46 & Smelcerovic et al. (2008) \\
\hline & HPLC & 2.9 & - & - & Oktayoglu (2003) \\
\hline & HPTLC & 2.7 & - & - & Kırmızıbekmez et al. (2008) \\
\hline H. pruinatum & LC/MS & 0.36 & 1.18 & 0.05 & \multirow{2}{*}{ Smelcerovic et al. (2008) } \\
\hline \multirow{2}{*}{ H. scabrum } & LC/MS & 0.04 & 0.07 & 0.02 & \\
\hline & HPLC & 0.0046 & 0.0035 & - & Yesilada et al. (1995) \\
\hline H. triquetrifolium & LC/MS & 4.56 & 3.49 & 0.05 & Smelcerovic et al. (2008) \\
\hline H. venustum & HPLC & 0.03 & - & - & Ayan et al. (2004) \\
\hline
\end{tabular}

and butyl chlorogenate), seven flavonoids (quercetin, quercitrin, hyperoside, isoquercitrin, miquelianin, rutin and I3, II8-biapigenin) and two flavanols [(+)-catechin and (-)-epicatechin] were isolated from $H$. calycinum (Kirmizibekmez et al., 2008a). Four major quercetin glycosides (rutin, miquelianin, hyperoside and quercitrin) were separated and quantitatively determined in methanolic extracts of $H$. perforatum by employing High performance thin layer chromatography (HPTLC)densitometry (Kirmizibekmez et al., 2008b).

\section{BIOLOGICAL ACTIVITIES}

\section{Antioxidant activity}

Antioxidant activity of ethanol and water extracts of the flowers of $H$. venustum was investigated. They were found to possess strong reducing power, free radicals and hydrogen peroxide scavenging activity, as well as metal chelating ability (Spiteller et al., 2008). $H$. lysimachioides var. lysimachioides was investigated for in vitro antioxidant activity. It was observed that antioxidative activities of ethanol extracts of $H$. lysimachioides are comparable with vitamin $\mathrm{E}$, and it was concluded that the use of this extract could be useful in the management of cardiovascular disease in which atherosclerosis is important (Hakimoglu et al., 2007). 2,2Diphenyl-1-picrylhydrazyl (DPPH) radical-scavenging activities of fruiting and flowering samples of $H$. pamphylicum (e) have been investigated. Both plant samples were active in DPPH radical-scavenging activities assay which was carried out in comparison with ascorbic acid (Eroglu, 2007). Fruiting and flowering samples of $H$. montbretii and $H$. perforatum have been investigated for DPPH radical-scavenging activities and all plant samples were active, compared with ascorbic acid and a-tocopherol (Oktayoglu, 2003). Antioxidant activity of phenolic compounds isolated from $H$. hyssopifolium subsp. elongatum var. elongatum was 
determined, and all the compounds were found to be active (Cakir et al., 2003). The free radical scavenging activities of the compounds isolated from $\mathrm{H}$. calycinum were determined. Compounds showed strong DPPH and nitric oxide (NO) scavenging activities in a concentration dependent manner. (+)-Catechin and (-)-epicatechin were found to be the most active compounds (Kirmizibekmez et al., 2008a).

\section{Analgesic activity}

The mechanism of the analgesic activity caused by $H$. perforatum was investigated. The authors reported that endogenous opioid mechanisms related to OP1receptors play an important role in $H$. perforatum induced analgesia (Ozturk, 2001).

\section{Wound-healing activity}

Wound-healing effect of St. John's wort extract was investigated on cultured chicken embryonic fibroblasts. It was reported that $H$. perforatum extract exhibits a woundhealing activity whose mechanism of action is similar to that of titrate extract of Centella asiatica (Ozturk et al., 2007).

\section{Hepatoprotective activity}

The hepatoprotective activity of $H$. perforatum was investigated in vivo. The authors suggested that $H$. perforatum has a protective effect on the liver (Ozturk et al., 1992).

\section{Anti-inflammatory activity}

The probable anti-inflammatory effect of $H$. triquetrifolium was explored in a rat model of carrageenan induced inflammation. It was concluded that $H$. triquetrifolium extract may exert an antiinflammatory effect in rats (Ozturk et al., 2002).

\section{Anti-nociceptive activity}

Total extract of $H$. triquetrifolium exibited anti-nociceptive activity in the mouse (Apaydin et al., 1999).

\section{Anti-Helicobacter pylori activity}

The anti-Helicobacter pylori effect of the extracts and fractions obtained from $H$. perforatum was studied by using agar dilution method. $H$. perforatum extract showed inhibitory activity against the microorganism (Yesilada et al., 1999).

\section{Human leukocyte myeloperoxidase activity}

In vitro effects of $H$. perforatum, $H$. empetrifolium and $H$. triquetrifolium were investigated on human polymorphonuclear leukocyte myleloperoxidase (MPO) activity.

Each extract of Hypericum species reduced the peroxidative and chlorinating activity of human leukocyte MPO in concentration-dependent manner. The antiinflammatory activity of these species may be related with inhibition of MPO activity (Pabuccupglu et al., 2003).

\section{Antidepressant activity}

Anti-depressant effect of certain Hypericum species on animal models was summarized. It was observed that anti-depressant activity with the alcoholic extract of $H$. Calycinum, whose effects on the central nervous system of mice are almost equal to the extract prepared from $H$. perforatum. $H$. hyssopifolium ssp. elongatum var. elongatum, seems to have no anti-depressant activity (Ozturk, 1997). The effects of $H$. perforatum and $H$. calycinum on the central nervous system were investigated using various behavioural models, including swimming time, locomotor activity, tail-flick and hole-board experiments.

According to the results, it was found that the extracts prepared from $H$. perforatum and $H$. calycinum were as effective as anti-depressant drugs, desipramine and trimipramine used as reference. This conclusion suggested that the anti-depressant effect of $H$. calycinum may be as potent as that of $H$. perforatum and may be used for therapeutic purposes in depression (Ozturk et al., 1996).

\section{Substance dependence}

In a review study on $H$. perforatum and substance dependence, Uzbay (2008) discussed the effects of $H$. perforatum on substance dependence and its possible benefit. The results suggest that an extract of $H$. perforatum (HPE) has some beneficial effects on ethanol withdrawal syndrome and that HPE blocks caffeineinduced locomotor hyperactivity in mice. Furthermore, it was reported that HPE may be useful for the treatment of alcoholism in clinical trials (Uzbay et al., 2007; Coskun et al., 2006; Uzbay, 2008).

\section{DISCUSSION}

Among 100 Hypericum taxa growing widely in Turkey, some of them were investigated and many articles were published. Table 3 shows published articles about Turkish 
Table 3. Investigation on the Hypericum spp. of Turkey.

\begin{tabular}{|c|c|c|c|c|c|c|c|c|c|c|c|c|c|c|c|}
\hline \multirow[b]{2}{*}{ Species } & \multicolumn{14}{|c|}{ Investıgatıon } & \multirow[t]{2}{*}{ References } \\
\hline & 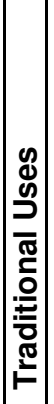 & 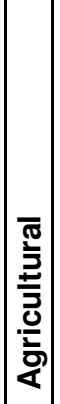 & 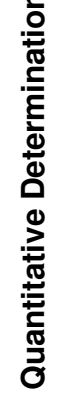 & 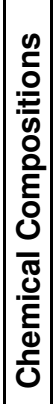 & 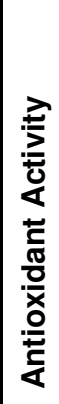 & 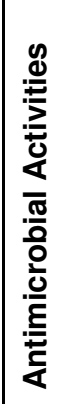 & 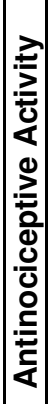 & 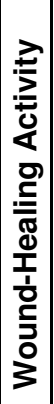 & 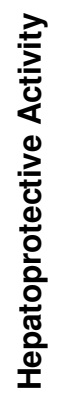 & 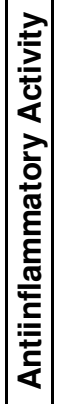 & 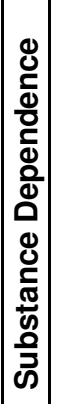 & 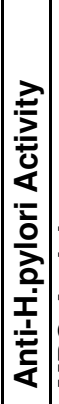 & (: & 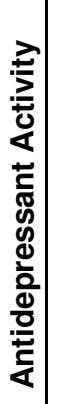 & \\
\hline H. adenotrichum (e) & & & & + & & & & & & & & & & & Erken et al. (2001) \\
\hline H. androsaemum & + & & + & & & & & & & & & & & & Kultur (2007) and Smelcerovic et al. (2008) \\
\hline H. atomarium & + & & & & & & & & & & & & & & Kultur (2007) \\
\hline H. aviculariifolium & + & & + & & & & & & & & & & & & Smelcerovic et al. (2008) \\
\hline $\begin{array}{l}\text { H. aviculariifolium subsp. depilatum var. } \\
\text { depilatum (e) }\end{array}$ & & + & + & & & & & & & & & & & & $\begin{array}{l}\text { Cirak et al. (2006a), Cirak et al. (2007c) and Ayan et al. } \\
(2004)\end{array}$ \\
\hline H. bithynicum & & & + & & & & & & & & & & & & Smelcerovic et al. (2008) \\
\hline H. bupleuroides & & + & & + & & & & & & & & & & & Cirak et al. (2006b) and Demirci et al. (2006) \\
\hline H. calycinum & + & & + & + & + & & & & & & & & + & + & $\begin{array}{l}\text { Erken et al. (2001), Kırmızıbekmez et al. (2008), Ozturk et al. } \\
\text { (1996) and Ozturk (1997) }\end{array}$ \\
\hline H. capitatum & & & & & & + & & & & & & & & & Sokmen et al. (1999) \\
\hline H. cerastoides & + & & & + & & & & & & & & & & & Erken et al. (2001) \\
\hline H. crenulatum $(\mathrm{e})$ & & + & & & & & & & & & & & & & Inan et al. (2003) \\
\hline H. empetrifolium & + & & & & & & & & & & & & + & & Pabuccuoğlu et al. (2003) and Kultur (2007) \\
\hline H. heterophyllum & + & & + & & & & & & & & & & & & Cirak et al. (2008) \\
\hline H. hircinum & & & & + & & & & & & & & & & & Demirci et al. (2008) \\
\hline H. hirsitum & & & + & & & & & & & & & & & & Smelcerovic et al. (2008) \\
\hline H. hyssopifolium & + & & + & + & & & & & & & & & & & Cakir et al. (2003) and Cakir et al. (2005) \\
\hline $\begin{array}{l}\text { H. hyssopifolium subsp. elongatum var. } \\
\text { elongatum }\end{array}$ & + & & & & + & & & & & & & & + & & Ozturk (1997) and Cakir et al. (2003) \\
\hline H. hyssopifolium var. microcalycinum & & & & + & & + & & & & & & & & & Toker et al. (2006) \\
\hline H. imbricatum & & & & & & + & & & & & & & & & Dulger (2005a) \\
\hline H. kazdaghensis $(\mathrm{e})$ & & & & & & + & & & & & & & & & Dulger and Gonuz (2005b) \\
\hline H. kotschyanun (e) & & & + & + & + & + & & & & & & & & & Unsal et al. $(2008,2009)$ \\
\hline H. linarioides & & & + & + & & + & & & & & & & & & $\begin{array}{l}\text { Cakir et al. (2005), Smelcerovic et al. (2008) and Ayan et al. } \\
\text { (2008) }\end{array}$ \\
\hline H. Iydium & & & + & & & & & & & & & & & & Cirak (2006c) \\
\hline H. Iysimachioides var. Iysimachioides & & & & + & + & + & & & & & & & & & Toker et al. (2006) and Hakimoglu et al. (2007) \\
\hline H. montanum & & & + & & & & & & & & & & & & Smelcerovic et al. (2008) \\
\hline
\end{tabular}


Table 3. Contd.

\begin{tabular}{|c|c|c|c|c|c|c|c|c|c|c|c|c|c|c|c|}
\hline H. montbretii & & & + & + & + & + & & & & & & & & & Erken et al. (2001) and Oktayoglu (2003) \\
\hline H. nummularioides & & + & + & & & & & & & & & & & & Cirak et al. (2006b) and Smelcerovic et al. (2008) \\
\hline H. olympicum & + & & & & & & & & & & & & & & Kultur (2007) \\
\hline H. orientale & + & & + & & & & & & & & & & & & Ayan et al. (2008) \\
\hline H. origanifolium & & + & + & & & & & & & & & & & & $\begin{array}{l}\text { Cirak et al. (2007c), Smelcerovic et al. (2008) and Ayan et al. } \\
(2008)\end{array}$ \\
\hline H. pamphylicum (e) & & & + & & + & + & & & & & & & & & Eroglu (2007) \\
\hline H. perfoliatum & & & + & + & & & & & & & & & & & Smelcerovic et al. (2008) and Cirak et al. (2008) \\
\hline H. perforatum & + & + & + & + & + & + & + & + & + & & + & + & + & + & $\begin{array}{l}\text { Cirak et al. (2006a, b, 2007c), Ayan et al. (2006), Ozturk et } \\
\text { al. (2007), Kırmızıbekmez et al. (2008) and Uzbay (2008) }\end{array}$ \\
\hline H. pruinatum & & + & + & & & & & & & & & & & & Cirak et al. (2006a) and Ayan et al. (2004) \\
\hline H. rupestre & & & & & & + & & & & & & & & & Dulger (2005a) \\
\hline H. salsugineum $(\mathrm{e})$ & & & + & + & + & + & & & & & & & & & Unsal et al. $(2008,2009)$ \\
\hline H. scabroides (e) & & & + & + & + & + & & & & & & & & & \\
\hline H. scabrum & + & & + & & & & & & & & & & & & $\begin{array}{l}\text { Smelcerovic et al. (2008), Kultur (2007) and Ayan et al. } \\
\text { (2008) }\end{array}$ \\
\hline H. thymopsis (e) & & & + & + & + & + & & & & & & & & & Unsal et al. $(2008,2009)$ \\
\hline H. triquetrifolium & + & & + & & & & + & & & + & & & + & & $\begin{array}{l}\text { Ozturk et al. (2002), Apaydın (1999), Pabuccuoglu et al. } \\
\text { (2003) and Kultur (2007) }\end{array}$ \\
\hline H. uniglandulosum (e) & & & + & + & + & + & & & & & & & & & Unsal et al. $(2008,2009)$ \\
\hline H. vaccinifolium & & & & & & + & & & & & & & & & Dulger (2005a) \\
\hline H. venustum & & & + & & + & & & & & & & & & & Spiteller et al. (2008) and Ayan et al. (2004) \\
\hline H. xylostrifolium & + & & & & & & & & & & & & & & Kultur (2007) \\
\hline
\end{tabular}

Turkish Hypericum species. Sixteen Hypericum have traditional uses. Hypericin, pseudohypericin and hyperforin percentages were determined in 20 species. The highest content of hypericin was found in $H$. triquetrifolium $(4.56 \mathrm{mg} / \mathrm{g})$ and $H$. perforatum $(3.47 \mathrm{mg} / \mathrm{g})$. Hyperforin was the highest in $H$. perforatum $(5.46 \mathrm{mg} / \mathrm{g})$ (Smelcerovic, et al., 2008). Volatile compounds were isolated and identified in 10 species, and phenolic compounds in only 4 species. Twentyone species were investigated for their activities in wound healing, hepatoprotective, anti-inflammatory, anti-ulcerogenic, analgesic, anti-oxidant, antinociceptive, anti-depressant, anti-microbial activities.
H. triquetrifolium showed anti-inflammatory and anti-nociceptive activities (Ozturk et al., 2002; Apaydin et al., 1999). The anti-depressant effect of $H$. calycinum was as potent as that of $H$. Perforatum, therefore it may be used for therapeutic purposes in depression (Smelcerovic et al., 2008). H. hyssopifolium subsp. elongatum var. elongatum, $H$. lysimachioides var. lysimachioides, $H$. montbretii, $H$. pamphylicum, $H$. venustum and $H$. perforatum were all found to have antioxidant properties (Cakir et al., 2003; Eroglu, 2007). All Hypericum extracts investigated were found to have anti-bacterial activity against Staphylococcus aureus. The essential oils of $H$. linarioides and $H$. capitatum showed anti-fungal and slight anti-retroviral activity against human immunodeficiency virus I (HIV-I), respectively (Cakir et al., 2005; Sokmen et al., 1999).

Although several Hypericum species have been used in folk medicine, only $H$. perforatum exists as its pharmaceuticals in the market. Studies on Turkish Hypericum species continued with an increasing trend and we hope that these species will become valuable in the future.

\section{REFERENCES}

Akgul A (2008). Ethnobotany at Midyat (Mardin). Master Thesis, Ege University, Institute of Science. Izmir.

Aktan T (2011). Ethnobotanical Studies of Yenisehir (Bursa) Villages. Master Thesis, Celal Bayar University, Institute of 
Science, Department of Botany, Manisa.

Apaydin S, Zeybek U, Ince I, Elgin G, Karamenderes C, Ozturk B, Tuglular I (1999). H. triquetrifolium Turra. extract exhibits antinociceptive activity in the mouse. J. Ethnopharmacol. 67:307-312.

Ayan AK, Cirak C (2008). Hypericin and Pseudohypericin Contents in Some Hypericum Species Growing in Turkey. Pharm Biol. 46(4):288291.

Ayan AK, Cirak C, Kevseroglu K, Zen T (2004). Hypericin in some Hypericum species from Turkey. Asian J. Plant Sci. 3(2):202-204.

Ayan AK, Yanar O, Cirak C, Bilgener M (2006). Variations in total phenolic during ontogenetic, morphogenetic and diurnal cycles in Hypericum species from Turkey. J. Plant Biol. 49(6):432-439.

Bombardelli E, Morazzoni P (1995). Hypericum perforatum. Fitoterapia 66:43-68.

Bruneton J (1995). Pharmacognosy, Phytochemistry, Medicinal Plants. Lavoisier Publishing, Paris 367-370.

Bulut Y (2006). Useful Plants of Manavgat District (Antalya). Master Thesis, Suleyman Demirel University, Institute of Science, Department of Biology. Isparta.

Buyukgebiz T (2006). Non-Wood Forest Products Of Sutculer District (Isparta). Master Thesis, Suleyman Demirel University, Department of Forest Engineering, Isparta.

Cakir A, Kordali S, Kilic H, Kilic H, Kaya E (2005). Antifungal properties of essential oil and crude extracts of $H$. linarioides_Bosse. Biochem. Syst. Ecol. 33(3):245-256.

Cakir A, Mavi A, Yildirim A, Duru ME, Harmandar M, Kazaz C (2003). Isolation and characterization of antioxidant phenolic compounds from the aerial parts of $H$. hyssopifolium L. by activity-guided fractionation. J. Ethnopharmacol. 87:73-83.

Cimen OD (2007). Ethnobotanical Studies About Traditional Medicines in Konya. Master Thesis, Gazi University, Institute of Health Science, Program of Phytotheraphy. Ankara Cirak C (2006c). Hypericin in $H$. lydium growing in Turkey. Biochem. Syst. Ecol. 34:897-899.

Cirak C, Kevseroglu K, Ayan AK (2007a). Breaking of seed dormancy in a Turkish endemic Hypericum species: $H$. aviculariifolium subsp. depilatum var. depilatum by light and some pre-soaking treatments. J. Arid Environ. 68(1):159-164.

Cirak C, Odabas MS, Ayan AK, Kevseroglu K (2006b). Modeling the temperature effect on days to germinate some Hypericum species from Turkey. Seed Technol. 28(1):58-63.

Cirak C, Radusiene J, Camas N (2008). Pseudohypericin and Hyperforin in two Turkish Hypericum Species: Variations Among Plant Parts and Phenological Stages. Biochem. Syst. Ecol. 36:377382.

Cirak C, Radusiene J, Ivanauskas L, Janulis V (2007b). Variation of bioactive secondary metabolites in $H$. origanifolium during its phenological cycle. Acta Physiol. Plant 29(3):197-203.

Cirak C, Radusiene J, Karabuk B, Janulis V (2007c). Variation of bioactive substances and morphological traits in $H$. perforatum populations from Northern Turkey. Biochem. Syst. Ecol. 35(7):403409.

Cirak C, Saglam B, Ayan AK, Kevseroglu K (2006a). Morphogenetic and diurnal variation of hypericin in some Hypericum species from Turkey during the course of ontogenesis. Biochem. Syst. Ecol. 34(1):1-13.

Coskun I, Uzbay TI, Ozturk N, Ozturk Y (2006). Attenuation of ethanol withdrawal syndrome by extract of Hypericum perforatum in Wistar rats. Fundam. Clin. Pharmacol. 20:481-488.

Demirci B, Kıyan T, Başer KHC (2008). Chemical composition of volatile oil of Hypericum hircinum L. J. Scient. Phytother, Fitomed Turkey 2(6):52.

Demirci F, Baser KHC (2006). Volatiles of $H$. bupleuroides Griseb. J. Essential Oil Res. 18(6):650-651.

Demirci S (2010). Ethnobotanical Study In Andirin (Kahramanmaras) District. Master Thesis, Istanbul University, Institute of Health Science, Department of Pharmaceutical Botany. Istanbul.

Dogrukol-Ak D, Kirimer N, Tuncel M, Aboul-Enein HY (2001). Determination of Rutin in $H$. perforatum extract by Capillary Electrophoresis. Anal. Lett. 34(2):185-191.

Dulger B (2005a). Antimicrobial studies on three Hypericum species from Turkey. S. Afr. J. Bot. 71(1):100-103.

Dulger B, Gonuz A (2005b). Antibacterial activity of the endemic $H$. kazdaghensis. Fitoterapia 76(2):237-239.

Ecevit GG, Ozhatay N (2006). An Ethnobotanical Study in Catalca (European Part of Istanbul) II. Turk J. Pharm. Sci. 3(2):73-89.

Erken S, Malyer H, Demirci F, Demirci B, Baser KHC (2001). Chemical Investigations on some Hypericum Species Growing in Turkey-I. Chem. Nat. Compounds 37(5):434-438.

Eroglu $E$ (2007). Investigaton of the $H$. pamphylicum in the Sense of Hypericin Content and Biological Activity. Master Thesis, Istanbul University, Department of Pharmacognosy.

Ezer N, Avcı K (2004). Traditional Medicines of Cerkes (Cankiri) Region. J. Hacettepe University, Faculty of Pharmacy 24(2):67-80.

Ezer N, Mumcu AO (2006). Folk Medicines in Merzifon (Amasya, Turkey). Turk. J. Bot. 30:223-230.

Hakimoglu F, Kizil G, Kanay Z, Kizil M, Isi H (2007). The effect of ethanol extracts of $H$. lysimachioides on lipid profile in hypercholesterolemic rabbits and its in vitro antioxidant activity. Atherosclerosis 192:113-122.

Honda G, Yesilada E, Tabata M, Sezik E, Fujita T, Takeda Y, Takaishi Y, Tanaka T (1996). Traditional medicine in Turkey VI. Folk medicine in West Anatolia: Afyon, Kütahya, Denizli, Muğla, Aydın provinces. J. Ethnopharmacol. 53:75-87.

Inan M, Kirici S (2003). The possibilities of domestication of some endemic Achillea and Hypericum species. Agric. Mediterr 133(2):124-129.

Keskin M, Alpınar K (2002). Ethnobotanical Studies About Kışlak (Yayladağı-Hatay). J. OT Syst. Bot. 9(2):91-100.

Kırmızıbekmez H, Celep E, Bardakcı H, Yeşilada E (2008). Quantitative determination of hypericin on Hypericum perforatum by using HPTLC. J. Sci. Phytother. Fitomed Turk. 2(6):43.

Kızılarslan C (2008). An Ethnobotanical Survey in The South Part of İmit Gulf. Master Thesis, Istanbul University, Institute of Health Science, Department of Pharmaceutical Botany. Istanbul.

Kirmizibekmez H, Atay I, Yesilada E (2008b). Determination of Four Major Flavonoids in the Methanolic Extract of Hypericum perforatum by HPTLC-Densitometry. Planta Medica 74(9):1103.

Kirmizibekmez H, Bassarello C, Pizza C, Celep E, Atay I, Mercanoglu G, Yesilada E (2008a). Antioxidant Phenolics From Hypericum calycinum. Planta Medica 74(9):951.

Kultur S (2007). Medicinal plants used in Kırklareli Province (Turkey). J. Ethnopharmacol. 111:341-364.

Mart S (2006). An Ethnobotanical Investigation of The Natural Plants Using By Inhabitants in Bahce and Hasanbeyli Districts of Osmaniye Province. University of Cukurova, Institute of Natural and Applied Sciences, Department of Biology, Adana.

Oktayoglu E (2003). Investigaton of the H. montbretii in the Sense of Hypericin Content and Biological Activity. Master Thesis, Istanbul University, Department of Pharmacognosy, Istanbul.

Ozturk B, Apaydin S, Goldeli E, Ince I, Zeybek U (2002). H. triquetrifolium Turra. extracts exhibits antiinflammatory activity in the rat. J. Ethnopharmacol. 80:207-209.

Ozturk N, Korkmaz S, Ozturk Y (2007). Wound-healing activity of St. John's Wort $(H$. perforatum L.) on chicken embryonic fibroblasts. J. Ethnopharmacol. 111:33-39.

Ozturk Y (1997). Testing the Antidepressant Effects of Hypericum Species on Animal Models. Pharmacopsychiatry 30:125-128.

Ozturk Y (2001). Possible mechanism of the analgesic effect of St. John's Wort. Fundam. Clin. Pharmacol. 15(1):113-153.

Ozturk Y, Aydin S, Baser KHC, Kirimer N, Kurtar-Ozturk N (1992). Hepatoprotective Activity of $H$. perforatum L. Alcoholic Extract in Rodents. Phytother. Res. 6:44-46.

Ozturk Y, Aydin S, Beis B, Baser KHC, Berberoglu H (1996). Effects of $H$. perforatum and $H$. calycinum extracts on Central Nervous System in mice. Phytomedicine 3(2):139-146.

Pabuccuoglu A, Konyalıoglu S, Bas M, Elgin-Meral G (2003). The in vitro effects of Hypericum species on human leukocyte myeloperoxidase activity. J. Ethnopharmacol. 87:89-92.

Sezik E, Yesilada E, Honda G, Takaishi Y, Takeda Y, Tanaka T (2001). Traditional medicine in Turkey X. Folk medicine in Central Anatolia. J. Ethnopharmacol. 75:95-115.

Smelcerovic A, Zuehlke S, Spiteller M, Raabe N, Özen T (2008). Phenolic constituents of 17 Hypericum species from Turkey. Biochem. Syst. Ecol. 36(4):316-319. 
Sokmen A, Jones BM, Erturk M (1999). Antimicrobial Activity of Extracts from the Cell Cultures of some Turkish Medicinal Plants. Phytother. Res.13:355-357.

Spiteller M, Ozen T, Smelcerovic A, Zuehlke S, Mimica-Dukic N (2008). Phenolic constituents and the in vitro antioxidant activity of the flowers of $H$. venustum. Fitoterapia 79(3):191-193.

Tatlı I, Sahpaz S, Kupeli AE, Martin-Nizard F, Gressier B, Ezer N, Bailleul $F$ (2009). Antioxidant, anti-inflammatory and antinociceptive activities of Turkish medicinal plants. Pharm Biol. 47(9):916-921.

Toker Z, Kizil G, Ozen HC, Kizil M, Ertekin S (2006). Compositions and antimicrobial activities of the essential oils of two Hypericum species from Turkey. Fitoterapia 77(1):57-60.

Tuzlaci E, Aymaz PE (2001). Turkish folk medicinal plants, Part IV: Gönen (Balıkesir). Fitoterapia 72:323-343.

Tuzlaci E, Tolon E (2000). Turkish folk medicinal plants, Part III: Şile (Istanbul). Fitoterapia 71:673-685.

Unal E, Mavi A, Kara A, Cakir A, Sengul M, Yildirim A (2008). Antimicrobial and Antioxidant Activities of Some Plants Used as Remedies in Turkish Traditional Medicine. Pharm Biol. 46(3):207224.

Unsal C, Kultur S, Eroglu E (2009). Investigation On Some Endemic Hypericum Species in Turkey. University of Istanbul, Project No: 442/27122005, Istanbul.

Unsal C, Ozbek B, Eroglu E, Kultur S (2008). Antimicrobial activity of some Hypericum species from Turkey. J. Sci. Phytother. Fitomed Turkey 2(6):74.
Uzbay TI (2008). Hypericum perforatum and Substance Dependence: A Review. Phytother. Res. 22:578-582.

Uzbay TI, Coskun I, Kayır H, Ozturk N (2007). Extract of Hypericum perforatum blocks Caffeine-induced Locomotor Activity in Mice: A Possible Role of Nitric Oxide. Phytother. Res. 21:415-419.

Vural G (2008). Ethnobotanical Features Some Of The Willd Plants On The Honaz Mountain And Its Environment Ethnobotanic. Master Thesis, Afyon Kocatepe University, Graduate School of Natural and Applied,Sciences, Afyon.

Yesil Y (2007). An Ethnobotanical Study in Kürecik District (Malatya/Akçadag). Master Thesis, Istanbul University, Institute of Health Science, Department of Pharmaceutical Botany, Istanbul.

Yesilada E, Gurbuz I, Shibata H (1999). Screening of Turkish antiulcerogenic folk remedies for anti-Helicobacter pylori activity. J. Ethnopharmacol. 66:289-293.

Yesilada E, Honda G, Sezik E, Tabata M, Fujita T, Tanaka T, Takeda Y, Takaishi $Y$ (1995). Traditional medicine in Turkey V. Folk medicine in the inner Taurus Mountains. J. Ethnopharmacol. 46:133-152.

Yesilada E, Honda G, Sezik E, Tabata M, Goto K, Ikeshiro Y (1993). Traditional medicine in Turkey IV. Folk medicine in the Mediterranean subdivision. J. Ethnopharmacol. 39:31-38. 